\title{
RESENHA
}

\section{Cristianismos em conflito}

Multiple forms of christianity in conflict Cristianismos en conflito

\section{Carlos Caldas}

COX, Harvey. O futuro da fé. São Paulo: Paulus, 2015, 292p.

O futuro da fé, de Harvey Cox (n. 1.929) integra a coleção "Novos caminhos da teologia", coordenada com muita competência pelo Professor Jung Mo Sung, da Universidade Metodista de São Paulo. Cox, que foi professor na Faculdade de Teologia da Universidade de Harvard, de 1965 a 2009, é reconhecido como um dos teólogos protestantes mais criativos e lúcidos da segunda metade do século XX e destes primeiros anos do século atual. Uma simples vista d'olhos nos títulos de seus livros deixa claro como em Cox sobejam a criatividade e a facilidade para descobrir temas, "diferentes", por assim dizer, transformando-os em loci de investigação teológica: $A$ festa dos folioes (publicado no Brasil pela Editora Vozes, em 1974, é estudo pioneiro sobre a festa como tema teológico), Que a serpente não decida por nós (publicado no Brasil, em 1970,pela Editora Civilização Brasileira, sobre o processo de humanização plena ao assumir responsabilidade nas escolhas do dia a dia da vida, tema que retomou em When Jesus Came to Harvard (2016, não publicado no Brasil) e seu clássico $A$ cidade secular (obra pioneira no estudo da secularização da sociedade ocidental) são apenas alguns exemplos. Cox, que já esteve algumas vezes no Brasil, também tem escrito a respeito do diálogo

Professor do Programa de Pós-Graduação em Ciências da Religião da PUC Minas. Doutor em Ciências da Religião pela UMESP. E-mail: crcaldas2009@hotmail.com 
inter-religioso (Turning East, de 1977, ainda não disponível em língua portuguesa) e acerca do impacto do pentecostalismo em nível mundial (Fire from Heaven. The Rise of Pentecostal Spirituality and the Reshaping of Religion in the Twenty-First Century, 2001), também ainda inédito no Brasil.

O futuro da fé é seu - por enquanto - mais recente trabalho. A criatividade do autor se manifesta nos títulos e subtítulos sugestivos e provocantes dos capítulos (15 ao todo), absolutamente incomuns em estudos acadêmicos. Alguns exemplos: Papa-Léguas e o Evangelho de Tomé. O que acontece quando não foi realmente desse jeito? (c.4), Não almocei com o Prefeito. Como consertar o papado (c. 8), Rocky, Maggie e Barry: prazer em conhecer. Qual Bíblia é seguida pelos seguidores da Biblia? (c. 11), Sangue no altar da divina providência. A teologia da libertação e o renascimento da fé (c. 13). Nesses capítulos, Cox demonstra profunda erudição, entabulando uma conversação entre fontes clássicas da teologia, a história das origens cristãs, a sociologia da religião e a cultura popular, em linguagem simples e direta. Suas conclusões, na maioria das vezes, são muito argutas, e revelam bastante coragem ao apresentá-las. Tudo isso mesclado com elementos de narrativa autobiográfica, que funcionam como "janelas" no texto, permitindo a entrada de luz e ar fresco na "casa" do livro, que dessa maneira fica mais interessante que se fosse apenas exposição conceitual teórica e abstrata. Os exemplos dados por Cox para ilustrar os "pontos" do arrazoado defendido no livro, extraídos da cultura popular, conferem alto poder de comunicação ao seu texto. Haja vista o capítulo quarto mencionado, quando no título do capítulo, e depois no corpo do mesmo, faz menção ao Papa-Léguas, um conhecido personagem de desenhos animados (cartoons) dos Estados Unidos que se tornou muito popular no Brasil.

A tradução na maior parte das vezes foi muito bem feita, salvo uma ou outra pequenina exceção.Três exemplos: na página 187, há uma referência à ênfase protestante fundamentalista em ser "renascido". Muito provavelmente o original em inglês traz reborn, que na literatura especializada em português é traduzido como "nascido de novo" (seguindo o texto de João 3.7 da versão Revista e Atualizada de João Ferreira de Almeida, a preferida dos evangélicos brasileiros). Na página 198, há uma referência ao conhecido pregador evangélico estadunidense Dwight Moody como “avivacionista”. Provavelmente, o original em inglês traz revivalist, que geralmente é traduzido na literatura especializada em português como "avivalista". Na página 211, há uma referência a "Barnabás" (Barnabas em inglês), mas a tradução consagrada pelo uso nas 
versões da Bíblia em português é Barnabé. Mas esses são detalhes pequeninos, que em nada diminuem a boa qualidade da tradução.

A tese de Cox é que a história do cristianismo pode ser dividida em três períodos ou fases: a Era da Fé, a Era da Crença e a Era do Espírito. Cox estabelece uma distinção vital para a compreensão da proposta do seu livro: a diferença entre fé e crença. Para Cox, fé é um compromisso de vida com o projeto de vida de Jesus de Nazaré, e crença é a adesão intelectual a afirmações racionais sistematicamente organizadas a respeito de Jesus e de Deus. Enquanto a fé se expressa na caminhada da vida - não é coincidência que, na narrativa de Atos, os primeiros seguidores de Jesus eram conhecidos como "os do Caminho" - a crença se expressa em credos, confissões e catecismos, que devem ser aceitos integralmente. Finalmente, a Era do Espirito é e será para Cox como que um retorno à Era da Fé. Cox entende que a Era da Crença não acabou de todo, mas estaria dando sinais de cansaço, esvaziamento e enfraquecimento, enquanto a Era do Espírito ainda não irrompeu com toda a sua força, mas estaria dando sinais inequívocos que está chegando, e não pode ser parada nem bloqueada.

A primeira, a Era da Fé, correspondendo, grosso modo, aos primeiros três séculos da era cristã (p. 103). Nesse período inicial, a fé em Jesus era mais vivida que interpretada racionalmente. Por meio da solidariedade para com os pobres e os mais vulneráveis da sociedade, reuniões em pequenos grupos que não tinham modelos de liderança organizados de maneira hierárquica rígida, os primeiros seguidores de Jesus viviam na esperança da irrupção escatológica plena do reinar de Deus (expressão que Cox prefere à conhecida "Reino de Deus"), e seguiam animados pela dinâmica do Espírito, e não pela força do poder político.

Conforme Cox, a Era da Crença começa já no período patrístico, quando acontece o que judiciosamente o autor interpreta como a "involução da fé em crença" (o subtítulo do quinto capítulo, p. 103). Desde então, o cristianismo tem sido marcado mais por disputas internas de poder que pela vivência propriamente da fé. Um trecho do mencionado quinto capítulo resume com exatidão todo o seu conteúdo:

A redescoberta atual do cristianismo primitivo ilumina essas disputas. O retrato que hoje surge indica que uma grande mudança começou sob pequenos aspectos, poucas décadas depois da vida de Jesus, e congelou-se num padrão permanente no fim do século III e no início do século IV, quando os líderes cristãos começaram a erigir hierarquias e a fabricar credos e a exigir que o 
povo os aceitasse. Depois disso, a composição de credos rapidamente tornou-se um hábito - uns diriam um vício - e continuou desde então, estabelecendo as bases de todos os fundamentalismos cristãos posteriores. Durante todo o início da Idade Média, credos eram produzidos em série, assim como as amargas disputas por eles engendradas. Durante a Reforma Protestante do século XVI, os líderes eclesiásticos ainda estavam formulando confissões conflitantes e afirmações contraditórias de crenças. Ainda em 1950, o papa Pio XII promulgou um dogma, o da assunção da Virgem Maria, em que todos os católicos deveriam crer a partir daquele momento. Hoje os fundamentalistas protestantes ainda se agarram a listas de crenças que insistem ser inegociáveis e sem as quais não é possível ser um verdadeiro cristão. Nos anos da Era da Crença, o resultado líquido dessa criação compulsiva de credos foi que a esperança de um mundo diferente que tinha dado vida ao cristianismo primitivo desvaneceu. Os teólogos católicos identificavam o Reino de Deus com sua igreja. Muitos protestantes jogavam-no para um além. Enquanto isso, sistemas de crenças obrigatórias quase eclipsaram a fé e a esperança (p. 104-105).

Cox irá descrever nos capítulos seguintes sua interpretação do que aconteceu como cristianismo por conta do predomínio da crença sobre a fé: uma decadência, não como instituição, mas como sistema de vida. O cristianismo adquire poder, alia-se ao Estado, estabelece uma aliança entre trono e altar, racionaliza-se, cria o modelo de cristandade com seu "credismo competitivo" (p. 108), torna-se intolerante e persegue, com violência simbólica, e até mesmo física, quem confessa desvios e interpretações diferentes da interpretação oficial. Um olhar, mesmo superficial, para o protestantismo brasileiro contemporâneo, comprova o acerto da observação de Cox.

A propósito, o capítulo 10 - Leve-os para o bote salva-vidas. O pathos do fundamentalismo (p. 187-202) - é, com perdão do trocadilho, fundamental para uma compreensão adequada da proposta do livro como um todo. Cox narra sua experiência como jovem estudante de graduação quando se envolveu com a InterVarsity Christian Fellowship, britânica de origem (conhecida no Brasil como Aliança Bíblica Universitária), entidade paraeclesiástica evangélica que atua no meio estudantil universitário. $\mathrm{Na}$ definição do próprio Cox, um dos objetivos (da InterVarsity) "era dar uma espécie de respeitabilidade intelectual ao que na verdade era uma versão fundamentalista do cristianismo, que tinha sido acusada - muitas vezes corretamente - de anti-intelectualismo” (p. 190). Esse juízo de Cox soa, no mínimo, hiperbólico. Definir a InterVarsity como “anti-intelectual” é, na prática, uma contradição de termos. 
Outro exemplo de argumentação que apela para a hipérbole, o que faz que a conclusão vá além do que as fontes estudadas permitem, encontra-se no capítulo 11 (Rocky, Maggie e Barry: prazer em conhecer. Qual Bíblia é seguida pelos seguidores da Bíblia?, p. 203-222). Conforme Cox:

Como aquilo que referimos por "Bíblia" vem mudando a cada século, com vários livros sendo incluídos ou excluídos dependendo do clima teológico, seria útil para os cristãos "que seguem a Bíblia" realizar um experimento imaginário. E se eles fossem cristãos seguidores da Bíblia no segundo século depois de Cristo? Naquela época, a única Bíblia que os cristãos tinham era o Antigo Testamento. O Novo Testamento ainda não tinha sido compilado. E se eles vivessem numa época em que a Primeira Epístola de Clemente e o Apocalipse de Pedro estavam sendo lidos em muitas congregações, com as várias cartas de Paulo? Muitos cristãos na época queriam incluir esses livros no Novo Testamento, mas eles acabaram não entrando. E se os nossos seguidores da Bíblia vivessem no século XV, quando os livros “apócrifos” que os protestantes excluíram poucas décadas depois ainda eram considerados Sagradas Escrituras e lidos nas igrejas (como são lidos ainda hoje nas igrejas católicas). A ideia de que "a Bíblia" sempre foi o mesmo livro um ano após o outro e de que você ou acreditava nela ou não acreditava pode ser reconfortante, mas não tem base na realidade (p. 204-205).

Não se há de negar o acerto da argumentação de Cox, nesse parágrafo. Mas não é possível afirmar que a Bíblia vem mudando a cada século. Não é bem assim... Nesse mesmo capítulo, ao comentar sobre o final do Evangelho de Marcos, Cox exagera ao discorrer a respeito das diferenças entre os manuscritos disponíveis do capítulo 16 (a que termina no v. 8, e é consensualmente tida pelos especialistas em manuscritologia bíblica como a melhor, e a outra, que vai até o v. 20, conquanto universalmente entendida como inferior à versão mais curta, aparece em todas as versões da Bíblia). Nesse trecho do capítulo, Cox faz um strawman, um "espantalho", isto é, constrói seu adversário para depois desconstruí-lo. Esse procedimento é muito popular no meio acadêmico, praticado por estudiosos de literalmente todas as tendências e escolas, muito embora não seja exatamente o mais honesto intelectualmente. A despeito dessas críticas que podem ser levantadas a Cox, não se pode deixar de mencionar que sua percepção da Bíblia é de uma fineza rara: "A Bíblia está mais para Shakespeare do que para um livro-texto de história antiga. Não vá atrás de história em sentido moderno, nem de geologia, nem de respostas rápidas para problemas éti- 
cos” (p. 220). Nenhum fundamentalista protestante do mundo concordaria com essa afirmação.

Apesar de sua perspicácia, algumas vezes Cox desliza em algumas de suas interpretações. Exemplo: no início do sexto capítulo ("O bispo é seu Sumo Sacerdote e Grande Rei”. A ascensão da casta clerical) Cox menciona a cerimônia de abertura da Assembleia Geral do Conselho Mundial de Igrejas em Canberra, Austrália, em 1991, conduzida por uma jovem teóloga coreana (Chung Hyung Kyung - mas Cox não lhe menciona o nome). Conforme Cox, a cerimônia em questão chocou os participantes do Atlântico Norte e Leste da Europa por apresentar "dezenove dançarinos com gongos, sinos e baquetas, liderados por dois dançarinos aborígenes de tanga e com o corpo pintado" (p. 119). Mas não foi exatamente esse o motivo da celeuma. O que aconteceu, mas Cox não citou, é que naquela cerimônia Chung Hyung Kyung realizou um ritual da antiga tradição xamânica coreana de invocação de espíritos, algo que definitivamente nunca fez e não faz parte de qualquerramo da tradição cristã. Quanto a isso, há que se tomar muito cuidado para tecer uma crítica a Cox: por um lado, ele está coberto de razão ao apontar para os prejuízos causados ao cristianismo ao substituir fé por crença, exigindo “aceitação integral” dos pontos desta. Por outro lado, ao mesmo tempo, Cox parece ter uma análise um tanto idealizada, ingênua e romântica dos primeiros tempos do cristianismo: "Os primeiros cristãos não lidavam com a dissonância tentando impor um sistema uniforme de doutrinas e ritos. No lugar disso, eles recebiam de braços abertos um amplo conjunto de expressões e confiavam que o Espírito, não uma hierarquia ou credo, manteriam (sic) sua unidade no amor" (p. 120). Há controvérsias quanto a essa interpretação de Cox. Essa afirmação pode ser problematizada.

Questiona-se também a afirmação de Cox (ex.: p. 28, repetida nas p.200-201) que o fundamentalismo teológico está diminuindo. Talvez nos Estados Unidos, mas no Brasil, o fundamentalismo teológico de corte protestante com pretensões calvinistas segue vivo e ativo. Faltou um pouco de cuidado na elaboração dessas afirmações que, como estão, transmitem a impressão que o fundamentalismo está perdendo sua influência em toda parte, o que absolutamente não corresponde à realidade. Quanto ao mais, as considerações de Cox quanto ao fundamentalismo (não apenas protestante, mas também islâmico, judaico e católico), são judiciosas e bem observadas. A conclusão do capítulo, narrada na primeira pessoa do singular, é particularmente interessante: 
Tendo experimentado, antes, ao menos uma centelha do vigor que motiva os fundamentalistas cristãos, fico sempre fascinado por seus movimentos e ainda sinto certa empatia por eles. Não consigo deixar de admirar seu compromisso e sua força. Às vezes ainda me pego cantarolando os majestosos hinos que aprendi com eles. No entanto, também sei quanto esforço é preciso para ser fundamentalista. Pode ser cansativo. Você precisa lutar constantemente não só contra o ceticismo das pessoas à sua volta, mas também contra as dúvidas que surgem em você mesmo. Os fundamentalistas despertam em mim tristeza mais do que tudo. Seu pathos é desperdiçar tanta energia numa causa perdida (p. 202, grifo do autor).

Outro problema da argumentação é que algumas das conclusões de Cox são ancoradas em análises feitas a distância. Exemplo: na página 185, Cox menciona o apoio evangélico dado a Luis Inácio Lula da Silva por ocasião de sua primeira eleição à presidência da República. O leitor desinformado pensará que todos os evangélicos brasileiros apoiaram Lula, o que simplesmente não foi verdade na época, como também não é hoje.

Os últimos capítulos revelam o que Cox entende que são sinais e anúncios da chegada da Era do Espírito, "um prenúncio do renascimento de uma fé baseada em efetivamente seguir Jesus e não em concordar com afirmações a respeito dele" (p. 223). Cox apresenta exemplos contemporâneos de resgate da vida cristã não como repetição de fórmulas doutrinárias, mas de mostras concretas que apontam para os cristãos como sendo o "povo do Caminho" (p. 227), ou seja, uma volta ao início de tudo. Em outras palavras: um cristianismo "pós-dogmático" (p. 282). Nessa parte de seu livro, Cox trabalha com observações já apresentadas por autores como o sociólogo da religião britânico Philip Jenkins (inter alia, A próxima cristandade. A chegada do cristianismo global. Rio de Janeiro: Record, 2004), que mostra como o cristianismo tem deixado de ser uma tradição do Atlântico Norte para ser cada vez mais não branco, pobre e de tendências pentecostais. Em um trecho assaz curioso, Cox afirma:

Na Ásia, suas culturas foram alimentadas não por Homero e Platão, mas pelo Ramayana, pelos Sutras e pelo Tao Te Ching. Na África, foram mantidas por um amontoado de rituais locais, por ritos costumeiros de cura e pela veneração dos ancestrais. Esse recente deslocamento também não é só cultural ou religioso. Ele também tem a ver com justiça. Como a vasta maioria das pessoas nessa "nova cristandade" não é nem branca nem bem de vida, suas questões estão menos centradas na existência ou inexistência de Deus do que 
em porque a pobreza e a fome ainda espreitam o mundo de Deus. Pouco admira que a teologia da libertação, o movimento teológico mais criativo do século XX, não tenha surgido em Marburg ou Yale, mas nos barracos de papelão do Brasil e nas favelas da Coreia do Sul (p. 230-231, grifos do autor).

De fato, Cox usa como exemplos do que entende são os sinais da vinda da Era do Espírito o surgimento da Teologia da Libertação (TdL) e o pentecostalismo. A propósito da TdL, Cox aponta:

Ela (isto é, a TdL) não nasceu nos auditórios de Tübingen nem nas bibliotecas da Universidade Gregoriana, em Roma. Não é uma teologia “de cima para baixo", mas uma teologia que circula "de baixo para cima", de milhares de grupos e movimentos de base. Tendo-se originado na América Latina na década de 1960, ela rapidamente se espalhou pelo sul global, onde o cristianismo hoje cresce mais depressa (sic), na Coreia, no sudeste asiático, na África subsaariana e na Índia. O bispo Desmond Tutu, da África do Sul, assim como os teólogos "minjung" da Coreia, os teólogos "dalit" (os antigos “intocáveis”) da Índia e os líderes da igreja clandestina chinesa reconhecem sua dívida para com ela (p. 245-246, aspas do original).

O problema aí não é o que Cox afirma, mas o que deixa de afirmar: chega a ser incrível que ele não tenha mencionado Rubem Alves, de quem era amigo próximo (foi Cox quem prefaciou a edição em inglês de $A$ Theology of Human Hope, de Rubem Alves, publicada nos Estados Unidos, em 1969, em que pela primeira vez aparece a expressão "teologia da libertação").

Todavia, merece destaque a abordagem não preconceituosa de Cox ao pentecostalismo, que costuma ser deplorado tanto por fundamentalistas como também por teólogos que se pretendem progressistas e abertos.

Em suma: o livro é de leitura agradável por demais, rico e denso em conteúdo, comunicativo em sua linguagem, e provocante, o que deve ser o objetivo de todo pensador. Cox argumenta muito bem a favor de sua tese, que "todos os sinais sugerem que estamos prontos para adentrar uma nova Era do Espírito, e que o futuro será um futuro de fé” (p. 285). 